\title{
Altruistyczny wymiar konsumpcji kolaboratywnej - czy naprawdę istnieje? Na przykładzie wspólnego użytkowania sprzętu medycznego
}

\section{Does the altruistic dimension of the collaborative consumption really exist? The case of joint medical equipment usage}

\author{
mgr Agnieszka Małecka \\ Uniwersytet Ekonomiczny w Katowicach, doktorantka w Katedrze Zarządzania Relacjami Organizacji \\ ORCID: 0000-0002-7065-6289 \\ e-mail: agnieszka.malecka@ue.katowice.pl
}

\begin{abstract}
Konsumpcja kolaboratywna jest rozpatrywana w literaturze przez pryzmat m.in. pożyczania i ponownego wykorzystywania zasobów (Lessig, 2008), udostępniania produktów na rynkach wtórnych (Young, Hwang, McDonald i Oates, 2010) czy nawet w kontekście antykonsumpcji (Ozanne i Ballantine, 2010). Ponieważ zjawiska te stanowią zupełnie inne podłoże dla badania determinant rozwoju samej konsumpcji kolaboratywnej, pojawiła się potrzeba doprecyzowania zakresu znaczeniowego pojęcia, tak aby w sposób świadomy oddzielić te aktywności, które stanowić będą jej przejawy, od tych, które nimi nie są. Autorka niniejszego artykułu podejmuje próbę określenia zależności pomiędzy poziomem altruizmu konsumenta a skłonnością do uczestnictwa w konsumpcji kolaboratywnej1. Przeprowadzona analiza nie wykazała związku pomiędzy różnymi przejawami konsumpcji kolaboratywnej a poziomem altruizmu konsumentów, poza słabą korelacją pomiędzy poziomem altruizmu a deklaracją konsumentów do zaangażowania w konsumpcję kolaboratywną w przyszłości.
\end{abstract}

Keywords

konsumpcja kolaboratywna, sharing economy, altruizm, altruizm odwzajemniony, sprzęt medyczny

Collaborative consumption is considered in the literature through the prism of borrowing and reusing resources (Lessig, 2008), making products available on secondary markets (Young, Hwang, McDonald, Oates, 2010), or even in the context of anti-consumption (Ozanne and Ballantine, 2010). Since these phenomena, constitute a completely different ground for studying the determinants of the development of collaborative consumption itself, there appeared a need to clarify the semantic scope of the concept, in order to deliberately separate those activities that will constitute its manifestations, from those that are not. The author attempts to clarify the association between the level of consumer's altruism and the inclination to participate in collaborative consumption. The analysis did not show any relationship between the various manifestations of collaborative consumption and the level of consumer's altruism, apart from a weak correlation between the level of altruism and the willingness to be involved in collaborative consumption in the future.

Slowa kluczowe

collaborative consumption, sharing economy, altruism, reciprocal altruism, medical equipment

EL: D16, E21, D12, A14

Str. 21-27 


\section{Bibliografia}

Albinsson, P. A. i Yasanthi Perera, B. (2012). Alternative marketplaces in the 21st century: Building community through sharing events. Journal of Consumer Behaviour, 11(4), 303-315. https://doi.org/10.1002/cb.1389

Arsel, Z. i Dobscha, S. (2011). Hybrid pro-social exchange systems: The case of freecycle. NA - Advances in Consumer Research, 39, 66-67.

Barnes, S. J. i Mattsson, J. (2016). Understanding current and future issues in collaborative consumption: A four-stage Delphi study. Technological Forecasting and Social Change, 104, 200-211. https://doi.org/10.1016/j.techfore. 2016.01.006

Baumgartner, H. i Steenkamp, J. B. E. (2006). Response biases in marketing research. W: R. Grover i M. Vriens (red.), The handbook of marketing research (95-109). Thousand Oaks: Sage.

Bekkers, R. i Wiepking, P. (2011). A literature review of empirical studies of philanthropy eight mechanisms that drive charitable giving. Nonprofit and Voluntary Sector Quarterly, 40(5), 924-973. https://doi.org/10.1177/ 0899764010380927

Belk, R. (2014). You are what you can access: Sharing and collaborative consumption online. Journal of Business Research, 67(8), 1595-1600. https://doi.org/10.1016/j.jbusres. 2013.10.001

Botsman, R. i Rogers, R. (2010). What's mine is yours. The rise of collaborative consumption. Harper Collins.

Botsman, R. i Rogers, R. (2011). What's mine is yours: How collaborative consumption is changing the way we live. Harper Collins.

Bucher, E., Fieseler, C. i Lutz, C. (2016). What's mine is yours (for a nominal fee): Exploring the spectrum of utilitarian to altruistic motives for Internet--mediated sharing. Computers in Human Behavior, 62, 316-326. https://doi.org/ 10.1016/j.chb. 2016.04.002

Burgiel, A. (2015). Wspólna konsumpcja jako alternatywny model spożycia i jej przejawy w zachowaniach konsumentów. W: E. Kieżel i S. Smyczek (red.). Zachowania konsumentów. Procesy unowocześniania konsumpcji (153-192). Wolters Kluwer.

Clary, E. G., Snyder, M., Ridge, R. D., Copeland, J., Stukas, A. A., Haugen, J. i Miene, P. (1998). Understanding and assessing the motivations of volunteers: A functional approach. Journal of Personality and Social Psychology, 74(6). https://doi.org/10.1037/0022-3514.74.6.1516

Corciolani, M. i Dalli, D. (2014). Gift-giving, sharing and commodity exchange at Bookcrossing.com: New insights from a qualitative analysis. Management Decision, 52(4), 755-776. https://doi.org/10.1108/MD-03-2012-0241

Dalli, D. i Corciolani, M. (2008). Collective forms of resistance: The transformative power of moderate communities. International Journal of Market Research, 50(6), 757-775. https://doi.org/10.2501/S1470785308200195

Dyche, J. (2002). The CRM handbook: a business guide to customer relationship management. Addison-Wesley Professional.

Ertz, M., Durif, F. i Arcand, M. (2016). Collaborative consumption or the rise of the two-sided consumer. International Journal of Business and Management, 4(6), 195-209.

Ertz, M., Lecompte, A. i Durif, F. (2017). Dual roles of consumers. International Journal of Market Research, 59(6). https://doi.org/10.2501/IJMR-2017-040

Felson, M. i Spaeth, J. L. (1978). Community structure and collaborative consumption: A routine activity approach. American Behavioral Scientist, 21(4), 614-624. https://doi.org/10.1177/000276427802100411

Fine, S. H. (1980). Toward a theory of segmentation by objectives in social marketing. Journal of Consumer Research, 7(1), 1-13. https://doi.org/10.1086/208787

Guyader, H. (2018). No one rides for free! Three styles of collaborative consumption. Journal of Services Marketing, 32(6), 692-714. https://doi.org/10.1108/JSM-11-2016-0402

Harvey, J., Smith, A. i Golightly, D. (2017). Giving and sharing in the computer-mediated economy. Journal of Consumer Behaviour, 16(4), 363-371. https://doi.org/10.1002/cb.1499

Hawlitschek, F., Teubner, T. i Gimpel, H. (2018). Consumer motives for peer-to-peer sharing. Journal of Cleaner Production, 204, 144-157. https://doi.org/10.1016/j. jclepro. 2018.08.326

Hwang, J. i Griffiths, M. A. (2017). Share more, drive less: Millennials value perception and behavioral intent in using collaborative consumption services. Journal of Consumer Marketing, 34(2), 132-146. https://doi.org/10.1108/JCM-102015-1560

Janoś-Kresło, M. (2015). Postawy wobec konsumpcji kolaboratywnej rodzin z dziećmi z niepełnosprawnością. Konsumpcja i Rozwój, 4(13), 27-39.

Kalafatis, S. P., Pollard, M., East, R. i Tsogas, M. H. (1999). Green marketing and Ajzen's theory of planned behaviour: A cross-market examination. Journal of Consumer Marketing, 16(5), 441-460. https://doi.org/10.1108/ 07363769910289550

Lamberton, C. (2015). Consumer sharing: collaborative consumption, from theoretical roots to new opportunities. W: M. I. Norton, D. D. Rucker, i C. Lamberton (red.), Cambridge Handbooks in Psychology. The cambridge 
Handbook of Consumer Psychology (693-720). New York: Cambridge University Press. https://doi.org/10.1017/ CBO9781107706552.026

Lessig, L. (2008). Remix: Making Art and Commerce Thrive in the Hybrid Economy. Penguin. https://doi.org/ 10.5040/9781849662505

Lindblom, A. i Lindblom, T. (2018). Applying the extended theory of planned behavior to predict collaborative consumption intentions. W: A. Smedlund, A. Lindblom, i L. Mitronen (red.), Collaborative Value Co-creation in the Platform Economy (167-182). Singapore: Springer. https://doi.org/10.1007/978-981-10-8956-5

Małecka, A. i Mitręga, M. (2015a). Konsumpcja kolaboratywna jako innowacja w zachowaniach konsumenckich i bodziec innowacyjny dla przedsiębiorstw. Logistyka, (2), 961-968.

Małecka, A. i Mitręga, M. (2015b). Konsumpcja kolaboratywna - wyzwania pomiarowe i menedżerskie w kontekście tzw. ride sharing. Zeszyty Naukowe Uniwersytetu Szczecińskiego. Studia i Prace Wydziału Nauk Ekonomicznych i Zarzadzania, 39(2), 139-150.

McArthur, E. (2015). Many-to-many exchange without money: Why people share their resources. Consumption Markets i Culture, 18(3), 239-256. https://doi.org/10.1080/10253866.2014.987083

Mick, D. G. (1996). Are studies of dark side variables confounded by socially desirable responding? The case of materialism. Journal of Consumer Research, 23(2), 106-119. https://doi.org/10.1086/209470

Morgan, S. E. i Miller, J. K. (2002). Beyond the organ donor card: The effect of knowledge, attitudes, and values on willingness to communicate about organ donation to family members. Health Communication, 14(1), 121-134. https://doi.org/10.1207/S15327027HC1401_6

Ozanne, L. K. i Ballantine, P. W. (2010). Sharing as a form of anti-consumption? An examination of toy library users. Journal of Consumer Behaviour, 9(6), 485-498. https://doi.org/10.1002/cb.334

Paladino, A. (2005). Understanding the green consumer: An empirical analysis. Journal of Customer Behaviour, 4(1), 69102. https://doi.org/10.1362/1475392053750306

Paraskevaidis, P. i Andriotis, K. (2017). Altruism in tourism: Social exchange theory vs altruistic surplus phenomenon in host volunteering. Annals of Tourism Research, 62, 26-37. https://doi.org/10.1016/j.annals.2016.11.002

Payne, A. i Frow, P. (2013). Strategic Customer Management: Integrating Relationship Marketing and CRM. Cambridge University Press. https://doi.org/10.1017/CBO9781139057417

Piscicelli, L., Cooper, T. i Fisher, T. (2015). The role of values in collaborative consumption: Insights from a product-service system for lending and borrowing in the UK. Journal of Cleaner Production, 97, 21-29. https://doi.org/ 10.1016/j.jclepro.2014.07.032

Pyszka, A. (2016). Rozwój innowacyjnych przedsięwzięć w ramach ekonomii współdzielenia a wyzwania w obszarze zarządzania ich odpowiedzialnością. W: I. Jonek-Kowalska (red.), Implementacja koncepcji społecznej odpowiedzialności w organizacjach i gospodarce. Etyka Biznesu i Zrównoważony Rozwój. Interdyscyplinarne studia teoretyczno-empiryczne, (3), 105-120.

Ritzer, G. i Jurgenson, N. (2010). Production, consumption, prosumption: The nature of capitalism in the age of the digital 'prosumer'. Journal of Consumer Culture, 10(1), 13-36. https://doi.org/10.1177/1469540509354673

Rogall, H. (2010). Ekonomia zrównoważonego rozwoju: teoria i praktyka. Poznań: Zysk i S-ka.

Roos, D. i Hahn, R. (2017). Does shared consumption affect consumers' values, attitudes, and norms? A panel study. Journal of Business Research, 77, 113-123. https://doi.org/10.1016/j.jbusres.2017.04.011

Rozwadowska, E., Krajewska-Kułak, E., Guzowski, A., Wiśniewska, A. i Cybulski, M. (2012). Samoocena poziomu rozumienia empatycznego innych ludzi przez wolontariuszy medycznych. Palliative Medicine/Medycyna Paliatywna, (3).

Rubin, P. H. (2009). Altruism and self interest in medical decision making. The Journal of Law, Medicine $i$ Ethics, 37(3), 401-409. https://doi.org/10.1111/j.1748-720X.2009.00401.x

Rundle-Thiele, S. R., Gillespie, M. i Ball, K. (2007). The buck stops here: Should we consider performance rather than corporate social responsibility? Social Entrepreneurship, Social Change and Sustainability: Proceedings of the 2007 International Nonprofit and Social Marketing Conference, 182-188.

Scaraboto, D. (2015). Selling, sharing, and everything in between: The hybrid economies of collaborative networks. Journal of Consumer Research, 42(1), 152-176. https://doi.org/10.1093/jcr/ucv004

Trivers, R. L. (1971). The evolution of reciprocal altruism. The Quarterly Review of Biology, 46(1), 35-57. https://doi.org/10.1086/406755

Tussyadiah, I. P. (2015). An exploratory study on drivers and deterrents of collaborative consumption in travel. Information and communication technologies in tourism 2015 (817-830). Cham: Springer. https://doi.org/10.1007/978-3-31914343-9_59

Van De Camp, K., Vernooij-Dassen, M. J., Grol, R. P. i Bottema, B. J. (2004). How to conceptualize professionalism: A qualitative study. Medical Teacher, 26(8), 696-702. https://doi.org/10.1080/01421590400019518 
Wasko M. M. L. i Faraj, S. (2005). Why should I share? Examining social capital and knowledge contribution in electronic networks of practice, MIS Quarterly, 29(1), 35-57. https://doi.org/10.2307/25148667

Wilson, E. O. (2000). Socjobiologia. Poznań: Zysk i S-ka.

Wolska, G. i Bretyn, A. (2015). Consumer behaviour and its impact on the company's market position in terms of Corporate Social Responsibility. DIEM: Dubrovnik International Economic Meeting, 2(1), 127-142.

Young, W., Hwang, K., McDonald, S. i Oates, C. J. (2010). Sustainable consumption: Green consumer behaviour when purchasing products. Sustainable Development, 18(1), 20-31. 